\title{
Vizuální poezie v díle Václava Havla
}

\author{
Tereza DĚDINOvÁ \\ Masarykova Univerzita, Brno \\ tereza.dedinova@gmail.com
}

Recibido: Mayo de 2012

Aceptado: Diciembre de 2012

\begin{abstract}
Abstrakt
Studie se zaměřuje na vizuální poezii Václava Havla, v úvodu poskytuje stručný vhled do metody vizuální poezie, poté se soustředí na představení Havlova specifického tvưrčího přístupu. Na rozdíl od svých současníků se Havel neodklonil od verbální sémantiky textu směrem k převážně formálním experimentům. Jádro jeho textů leží ve zkoumání stereotypů myšlení i jazyka, frázovitosti a mnohomluvného nicneříkání.
\end{abstract}

Klíčová slova: vizuální poezie, Václav Havel, Antikódy, verbální sémantika, experimentální poezie

\section{La poesía visual en la obra de Václav Havel}

\section{Resumen}

El estudio está dedicado a la poesía visual de Václav Havel. En la introducción ofrece una introducción sucinta al método de la poesía visual, para después centrarse en la presentación del método creador específico de Havel. A diferencia de sus contemporáneos, Havel no se apartó de la semántica verbal del texto hacia experimentos de índole principalmente formal. El núcleo de sus textos consiste en la indagación de los estereotipos de pensamiento y lenguaje, la expresión mediante clichés y la locuacidad vacía.

Palabras clave: poesía visual, Václav Havel, Anticódigos, semántica verbal, poesía experimental

\section{Visual Poetry in Václav Havel’s Work}

\begin{abstract}
First, the study dedicated to the Václav Havel's visual poetry makes a brief introduction to the topic of working methods of visual poetry, second, it focuses on Havel's specific creative approach. Contrary to many of his contemporaries, Havel never diverted from verbal semantics towards the predominantly formal experiments. The essence of his texts lies in exploration of thought and language stereotypes, of phrases and voluble verbal vacancy.
\end{abstract}

Key words: Visual poetry, Václav Havel, Antikódy, verbal semantics, experimental poetry 


\section{Písmo-obraz, znak a prostor}

Metoda ozvláštnění vizuální složky textu, známá již v antickém Řecku ${ }^{1}$, se vontextu výrazněji projevuje od dvacátých let minulého století a tvoří nejpočetnější skupinu realizací experimentální poezie vůbec.

Od tradiční poezie přirozeně využívající vizuálních aspektů grafické struktury veršů se liší zásadní důležitostí vizuálního aspektu, který se stává základem výstavby celé básně.

Vizuální inovace působí vedle obsahové složky, nebo ji zcela zatlačuje do pozadí. Se zřetelem na př́tomnost sémantické stránky se vizuální poezie dělí na dvě základní skupiny: sémantickou a asémantickou.

Asémantické texty tvoří z jednotlivých znaků plošné a prostorové struktury nevázané na významovou interpretaci, ale na prostorové vztahy mezi svými prvky. Vznik těchto textů typicky souvisí s používáním psacího stroje.

Sémantické básně si stále zachovávají významovou informaci vedle vizuální.

Zvláštním př́ípadem jsou texty nesoucí mimoverbální sémantiku vizuální doplňující verbální význam textu o další související nebo kontrastující obsah.

Mimoverbální sémantika vzniká na základě grafických vlastností textu, který může být uspořádán do rozličných figurativních či nefigurativních znakủ. Typickým př́kladem nositele mimoverbální sémantiky je barva, at' již použitá pro zdůraznění určitého znaku (vybarvení písmen) nebo sama se znakem stávající (černá barva na místě slova ,černéc).

Př́pad, kdy se verbální a mimoverbální sémantika střetávají, se nazývá sémantickou komplikací. Jiří Valoch uvádí dvě základní polohy sémantické komplikace: kontrast a negaci dvou významů. Kontrastem je slovo „čern““ napsané červeně a negací slovo „kruh“ uspořádané do čtverce.

\section{Václav Havel - Antikódy}

Dramatik, spisovatel a politik Václav Havel je autorem sbírky experimentální poezie Antikódy, která vznikala zejména vnohé texty odpovídají. Roku 1993 sbírka vychází doplněna o vizuální básně pozdějšího data. V Havlově tvorbě zůstala ojedinělá a dle slov Josefa Hiršala „vznikla spíše na okraji jeho pokusů v dramatické oblasti“. Spojovací linie mezi Havlovými dramatickými texty a touto básnickou sbírkou leží především ve zkoumání stereotypů myšlení i jazyka, frázovitosti a mnohomluvného nicneříkání.

Havel se na rozdíl od většiny svých současníků v experimentální poezii neodklání od verbální sémantiky textu. Jeho poezie se nevzdává filozofického ani politického kontextu, naopak se parodickou formou, důvěrně známou z Havlových her, vyjadřuje $\mathrm{k}$ neslavné společenské situaci země uzavřené za železnou oponou. Samotné názvy mnohých básní jsou výmluvným dokladem této skutečnosti: Nástup, Konstruktivní satira, Opravil autor, Ideálně zorganizované umění, Vzor lid, Dvoji pojetí normalizace, (svobodný legální pták).

\footnotetext{
${ }^{1}$ Nejstarším známým př́íladem vizuální básně jsou básně Simiase Rhodského pocházející z antického Řecka ve třetím století před naším letopočtem; jeho texty vytvářejí vizuální konfigurace dvoubřité sekery a jiných předmětů.
} 
Havel v rozhovoru nad připravovaným vydáním sbírky Antikódy roku 1993 přiznává, že sice vždy vzhlížel k čisté konkrétní poezii oproštěné od verbální sémantiky a pozorně sledoval její tvůrce, sám však nebyl schopen asémantickou linii dodržet. Do jeho textů vždy pronikal satirický přesah. Slovy Josefa Hiršala sbírka Antikódy:

Na rozdíl od hlavního proudu konkrétní poezie měla další dimenzi: byla svým způsobem protestem, a to nikoli jen proti 'pocitově verbálním konvencím současné české poezie', ale, zvlášš ve své poslední fázi i jakousi artikulací absurdity tehdejších politických poměrů. Václav Havel se tu vyjadřoval komprimovaně a zřetelně, protože si bezesporu přál, aby mu co nejvíc čtenárư porozumělo a naplno ho pochopilo. Typogram se mu jeví jako maximálně vhodná forma. (HIRŠAL 1993a: 6)

Pevný směr a funkce básnických textů nezůstaly bez vlivu na jejich formální stránku. Podle výše uvedeného dělení vizuální poezie patří Havlovy typogramy převážně ke konstelacím, tedy $\mathrm{k}$ nejsnáze se nabízejícímu způsobu realizace poezie založené na vztazích mezi řetězcem několika slov². Jiř́i Valoch ve své studii upozorňuje, že Havlovi se málokdy podařilo vytvořit skutečně kvalitní a formálně vynalézavé texty: „Havlovi se ovšem nepodařilo objevit metodu, která by tyto oblasti umožňovala poeticky vyčerpat. Jednotlivé známé postupy jsou př́ípad od př́ípadu exploatovány podle momentální potřeby jednoho či několika nápadư“ (VALOCH 1970: 115). Nejvíce oceňuje některé vizuální metafory (např. kříž složený ze slova „život") a básně, v nichž se verbální sémantika střetává se sémantikou vizuální. Například báseň ve tvaru kruhu skládající se pouze ze slov vpřed (vpřed).

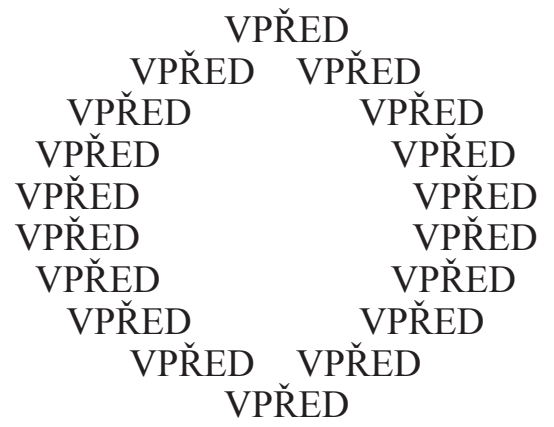

Václav Havel je autorem vizuální poezie, ve které je vůdčím principem sémantika, nikoli formální hra.

Základem je vzpoura proti nabubřelosti. Odmítnutí anonymity, automatizace a užvaněné důležitosti zakrývající prázdnotu a tupost.

\footnotetext{
2 Vycházíme zde ze základního dělení do pěti vzorů, které představila dvojice autorů a teoretiků experimentální poezie Josef Hiršal a Bohumila Grögerová.

Konstelace - sleduje prostorové a významové vztahy mezi několika plnovýznamovými slovy rozvrženými v prostoru. Partitura - text rozvržený do vertikálních či horizontálních konstelací podle hláskové skladby jednotlivých slov.

Portrét - hlásky obsažené ve jméně portrétované osoby dávají vzniknout dalším slovům, jež by dohromady měla tvořit imaginární portrét dotyčného. Hlásky $\mathrm{v}$ jednotlivých slovech jsou rozmístěny náhodně nebo na základě matematického klíče.

Mikrogram - spojuje sémantickou a vizuální stránku slova. Např́klad hlásky slova „,rty“ budou usporádány do tvaru rtů. Makrogram - slovně-výtvarná báseň. Například báseň vystavěná na symbolice kříže zaujímá plošný tvar kříže.
} 
Zásadní rysy Havlova tvůrčího př́ístupu vynikají i v těch nejméně vizuálně ozvláštněných textech. Zneužívaná slova ztrácejí smysl a stávají se prostředky neporozumění. V básni Vyrozuměni (320) to Havel zobrazuje postupným zastíráním a přepisováním opakujícího se slova až k nečitelnosti. Struktura básně přitom zdůrazňuje, že jde o proces. Obecné výrazy zastírající svou adresnost se stávají veřejným tajemstvím (jistí lidé a určité činy), přidaná hodnota slova pro zasvěcené spočívá v jeho skrytém významu (Potouchlost, Heisenbergưv princip určitosti, Uméní jinotaje). Halasně vyvolávaná hesla nejsou nic než absurdní splácaniny navzájem nesouvisejících výrazů, na které Havel odpovídá po svém: „At’ žije šalvěj! / pryč sptakopysky!“ (HAVEL 1993: 348). Jazyk přestává být komunikačním kódem a mění se v neprostupnou bariéru rozbíjející jakýkoli pokus o kontakt. Názorně je to zobrazeno v básni Bariéra, v níž dva subjekty prezentované zájmeny já a ty neprostupně odděluje zed', jejímž stavebním materiálem jsou pouze slova.

Ale sama slova a písmena se někdy dokážou vymknout přisouzené roli a vzbouřit se: báseň Parte ukazuje velmi netradiční pojetí tohoto textového útvaru. Namísto obvyklého rozloučení s milovaným (at' již upřímně či předstíraně) členem rodiny oznamuje smrt nenáviděného př́buzného a doporučuje adresátům, aby se neobtěžovali na pohřeb a na dotyčného rychle zapomněli. Následující Parte 2 začíná tradičním tónem, který je ale již od počátku komplikován útržkovitostí slov komolených vynechanými písmeny. Nakonec se písmena „utrhnou ze řetězu“ a celý text vyzní do ztracena. Zbydou z něho pouze samostatně stojící písmena $A$, která rozsypána v nesmyslném celku upozorňují na podobně nesmyslný celek smysluplného sdělení. Vzbouřené samohlásky vedle své funkce souřadicí spojky evokují nový začátek.

V Havlových textech se odráží princip gagu tak, jak jej autor popsal v eseji Anatomie gagu z roku $1963^{3}$. Gag podle Havla vzniká střetnutím dvou automatismů, z nichž ten druhý ozvláštňuje, polidštuje a depatetizuje ten první, typicky nepřiměřený, honosný a neuprímností zavánějící ${ }^{4}$. Gag je obranou proti odlidštěnosti, na místo nepřiměřených pocitů a reakcí staví - kontrastně - pocity a reakce obecně přiměřené a důvěrně známé, jakkoli nezapadající do stanoveného kontextu. Je tak vzpourou proti automatizované a neupř́ímné existenci a návratem k lidství: „gag probouzí zážitek absurdity tím, že ozvláštňuje (jako absurdní vyjevuje) takovou skutečnost, v níž je člověk nějakým způsobem společensky („objektivně“) odcizen sobě samému, aniž by si to přitom plně uvědomoval." 5

Gag v Havlově poezii nacházíme všude tam, kde je vedle sebe (za sebe) postaveno nesouměřitelné, kde za patetickým výkřikem následuje skeptické zaváhání, kde organizované sebejistoty kř́ží střízlivá pochybnost. Gagem je prohlášení Slibujeme, že už nebudeme blbnout, s kolonkami čekajícími na podpis Jana Husa a Josefa Švejka, gagem takřka ukázkovým je třemi tečkami doplněné $H m$ následující za sloupcem vykřičníky a kapitálami zdůrazněných výkřiků typicky uvozujících dobová velkohubá prohlášení: „PROHLAŠUJEME! / ŽÁDÁME! / STOJíME! / NEPOLEVÍME! / VYZÝVÁME!“ (HAVEL 1993: 347)

\footnotetext{
${ }^{3}$ Není bez zajímavosti, že esej vznikla ve stejné době jako značné množství Havlových vizuálních textů.

${ }^{4}$ Gagem je např́íklad slavnostní ceremoniál odhalování sochy Prosperity, který je narušen (zlidštěn) pohledem na spícího žebráka Chaplina schouleného v její náruči (HAVEL 1963: 1).

5 archive.vaclavhavel-library.org/kvh_search/itemDetail.jsp?id=601
} 
Zásadním tématem Havlovy tvorby 6 je odcizení se sobě samému a v Antikódech nalézáme i jeho explicitní zobrazení v podobě labyrintu oddělujícího dvě hlásky osobního zájmena $J \dot{A}$.

Vytečkovaný labyrint je současně překážkou propojení a jedinou možností k opětovnému setkání: budeme-li jej pečlivě sledovat, může nás dovést $\mathrm{k}$ cíli.

Obdobně cyklus Člověk v různých formách zobrazuje nesamozřejmost tohoto výrazu, rozličnost jeho chápání a přeneseně ztrátu sebe sama. Kontrastně vyniká ojedinělý a z řady „lidí“ (a dále lidu) vypadávající člověk (báseň 6) narušující pravoúhlou uspořádanost textu. Příznačný je rovněž rukopisný nápis člověk uprostřed struktury tvořené otazníky uzavírající celý cyklus a přesahující zpět k ostatním, čistě strojopisným textům.

Přestože Havlovy texty obecně akcentují verbální sémantiku, neměli bychom zapomenout na roli prostoru $\mathrm{v}$ jednotlivých básních a vztah prostoru zaujímaného jednotlivými slovy a znaky vůči prostoru nezaplněnému. Vzdálenost a napětí mezi slovy nesou specifickou výpověd’ vynikající nejvíce tam, kde je stránka „zaplněna“ pouze dvěma slovy a jejich vzájemnými vztahy. Na tomto principu jsou založeny básně Brněnský komplex a Mírové soužití; zatímco první báseň vystihuje komický ráz antagonismu mezi Brnem a Prahou (či snad lépe řečeno brněnského antagonismu namířeného ku Praze), druhá stejnými prostředky zpochybňuje platnost slovního spojení ve svém názvu a implicitně je označuje za protimluv. Mírové soužití se ukazuje být možným pouze $\mathrm{v}$ př́padě, kdy je mezi soužijícími (a $\mathrm{v}$ textu básně mezi oběma slovy) maximální možná vzdálenost ${ }^{7}$. Na představivosti (a míře pesimismu) čtenáŕe zůstává, zda zobrazené míŕí pouze $\mathrm{k}$ dobové situaci a paroduje oblíbenou frázi, nebo si nárokuje obecnější platnost. Odlišné je zaplnění prostoru dvěma slovy v básni Šetřte papírem!, která je satirickou odpovědí na ideologické kampaně pravidelně zaplavující obyvatelstvo soudobého Československa. Heslo zaplňující maximální prostor odkazuje $\mathrm{k}$ hromadám papíru (a pokácených stromů) obětovaných v rámci boje za ochranu lesů.

$\begin{array}{lll}\breve{\mathrm{S}} & \mathrm{e} & \mathrm{t} \\ \check{\mathrm{r}} & \mathrm{t} & \mathrm{e} \\ \mathrm{p} & \mathrm{a} & \mathrm{p} \\ \mathrm{i} & \mathrm{r} & \mathrm{e} \\ \mathrm{m} & & \text { ! }\end{array}$

Poněkud komplikovanější je pojetí prostoru tam, kde Havel přechází od konstelací k makrogramům. Peter Steiner ve studii „Moc obrazu: vizuální poezie Václava Havla" pátrá po textech, které specificky odpovídají na tehdejší schizofrenní situaci (co se ríká a co se řečeným myslí) formou sebereferenčního paradoxu ${ }^{8}$, jehož variantou je dvojitá vazba: střet zprostředkování sdělení a zprostředkovaného obsahu.

\footnotetext{
${ }^{6}$ Např́íklad viz Zahradni slavnost.

7 Prostou aplikací tohoto principu je umístění slova outsider do dolního rohu stránky (Slovníček 12).

8 ,Řečeno prostě, tvrzení typu ,já lžu“ nemůže nebýt dvojznačné, poněvadž pokud je pravdivé a já skutečně lžu, musí být současně i nepravdivé, protože v tom případě nelžu, a obráceně.“ (STEINER 2007: 111).
} 
Napětí tak vzniká směšováním neslučitelného, vnikají heterologická vyjádření (postrádající vlastnosti, které označují) ${ }^{9}$. Jako př́klad Steiner uvádí báseň Svoboda ${ }^{10}$.

$\begin{array}{cc}\text { S } & \text { S } \\ \text { V } & \text { V } \\ \text { S V O B O D A S V O B O D A } \\ \text { B } & \text { B } \\ \text { S V O B O D A S V O B O D A } \\ \text { D } & \text { D } \\ \text { A } & \text { A }\end{array}$

Specifickými makrogramy jsou básně ve tvaru křiže. Steiner na základě jedné z nich (kř́ž složený ze čtyřiapadesáti slov život) načrtává nejistou hranici mezi autologickým a heterologickým zobrazením představuje dvě základní možné interpretace básně: první, heterologická, chápe zobrazení jako negaci významu (život se stává smrtí), druhá odkazuje k notoricky známému rčení „život je křřž (STEINER 2007: 120). Dalším výkladem by mohlo být směřování života (životů) ke smrti, která mu dává konečný tvar a propojuje jednotlivé životy $\mathrm{v}$ jeden celek. Nejpravděpodobněji je podle nás báseň svérázným zobrazením dvojité vazby spojující obě základní interpretace v jedno. Básní-křížů je v Antikódech vícero: paragrafy $(\S)$ tvořený kříž jako pocta Bedřichu Fučíkovi, z písmen $x$ složený křřž s náhrobkem Zde padl jako obět složité situace a konečně v náhrobek s křřžem v cyklu Člověk.

Poslední dva př́ílady spojuje vizuální zpracování prostřednictvím znaku $x$ a obdobné vyznění. $X$ jakožto znak používaný typicky tam, kde chceme vyjádřit neurčitý počet a vlastnosti, oživuje dojem anonymity, odlidštění a automatizace, na které jsme již upozornili u jiných básní. Zároveň oba texty evokují tragikomičnost opět spjatou se soudobými událostmi. První z nich Steiner vzpomínaje Burianova osla interpretuje jako „pohřební řeč nad rakví reformního vedení KSČ““ po srpnu 1968 (STEINER 2007: 123). Druhý připomíná snahu (a současně nemožnost) rozdělit se, část své bytosti vystavit na odiv a druhou skrýt. Nakonec padají za obět' obě. Kontextově můžeme báseň opět vztáhnout $\mathrm{k}$ soudobému politickému a společenskému dění a požadavku „dvojí tvářre - veřejné a soukromé.

$\mathrm{K}$ pólu obrazu se blíží básně kombinující mikro- a makrogramy, napríklad Topinkovi využívající kontrastu hutného statického mikrogramu mrak s lehkým a svižným zobrazením větru. Druhou významovou rovinu tvoří připomenutí, že je to vítr, který rozhání mraky, nikoli naopak.

mrakmrakmrakmrakmrak

mrakmrakmrakmrakmrakmrakmrakmrakmrak

mrakmrakmrak mrakmrakmrakmrakmrakmrakmrakmrakmrak

mrakmrakmrak mrakmrakmrakmrakmrakmrakmrakmrakmrak

\footnotetext{
${ }^{9}$ Takové texty jsou druhou fází snahy o vyjádření vztahu mezi sdělením a jeho vizuálním zobrazením. V cyklu Slovníček, zařazeném v úvodních částech sbírky, pátrá Havel po vizuálním zobrazení souznějícím s významem sdělení (např̀. již citovaný Outsider) a vytváří tak sdělení autologická (vizuální zobrazení se shoduje s vyjádřením)

10 Podobně básně Vpřed a Šetřte papírem!
} 
mrakmrakmrak mrakmrakmrakmrakmrak mrak mrakmrakmrak mrakmrakmrakmrakmrak mrakmrakmrak mrakmrakmrakmrakmrakmrakmrakmrakmrak mrakmrakmrak mrakmrakmrakmrakmrakmrakmrakmrakmrakmrak mrakmrakmrak mrakmrakmrakmrakmrakmrakmrakmrakmrak mrakmrakmrakmrakmrakmrakmrakmrakmrakmrakmrakmrak mrakmrakmrak mrak mrakmrakmrakmrak mrakmrakmrakmrakmrakmrakmrakmrakmrakmrak mrakmrakmrakmrakmrakmrak

mrak

$\mathrm{V}$

V Antikódech nacházíme rovněž básně-příběhy, které svým pojetím prostoru mezi slovy dokumentují nějaký proces ${ }^{11}$. Vznik a vývoj manželství vypráví př́běh rozvíjejícího se vztahu (rozvíjejících se vztahů) mezi dvěma lidmi. Protipólem těchto „dynamických textů“ jsou básně evokující otupující monotonii politické mašinerie, která se opakováním pokouší (marně) dosáhnout zdání vývoje12. Jakákoli změna je však potlačena (At’ jde každý svou cestou).

Napětí mezi textem a prostorem, mezi vyřčeným a nevyřčeným Havel plně využívá v minicyklu Vzpomínka, Jiná vzpomínka a Vzpomínka nejtajnější. Čistá plocha papíru odkazuje k soukromým př́běhům, tajemstvím chvějícím se na hrotu pera.

\section{Z P O M ÍN K A N E J T A J N Ě J Š Í}

Ach ...

V tom je největší síla Havlových básní, ve stručnosti, nedořečenosti a značném prostoru ponechaném pro čtenářovu fantazii. Maximum výpovědi zprostředkované minimem znaků. Havel v Antikódech předestírá více otázek než odpovědí. Sbírka sama je svéráznou odpovědí na dobu vyznačující se pokládáním automatizovaných odpovědí na pseudootázky.

\footnotetext{
11 Např. již zmíněné Vyrozumění.

12 Steiner zde uvádí báseň sestávající se z opakujícího se hesla Za všestranný a harmonický rozvoj osobnosti! , na které dokládá umrtvující působení propagandy (STEINER 2007: 118).
} 


\section{Seznam literatury}

HAVEL, V. (1993): Antikódy, Odeon, Praha.

HIRŠAL, J. (1993a): „Antikódy aneb angažovaná artikulace absurdity“, in HAVEL, V. Antikódy, Odeon, Praha.

HIRŠAL, J., B. GRÖGEROVÁ (1993b): Vrh kostek, TORST, Praha.

PUTNA, M. C. (2011): Václav Havel, duchovní portrét v rámu české kultury 20. Století, Knihovna Václava Havla, o.p.s., Praha.

STEINER, P. (2007): „Moc obrazu: vizuální poezie Václava Havla“, Estetika, 44, 1-4, s. 107-124.

TAKENAMI, J. (2006): Japonská kaligrafie, Computer Press a.s., Brno.

PETRŽELKA, Z. (ed.) (1996): Uprostřed průmyslové noci, Větrné mlýny, Brno.

HORÁČEK, R., J. ZÁLEŠÁK (ed.) (2007): Teorie a praxe galerijní pedagogiky, vizuální kultura a výtvarná výchova, Masarykova univerzita, Pedagogická fakulta, Katedra výtvarné výchovy, Brno.

VALOCH, J. (1970): Experimentální poezie a její české realizace, Univerzita Jana Evangelisty Purkyně, Filozofická fakulta, Brno.

HAVEL, V. Anatomie Gagu. Dostupné z http://archive.vaclavhavel-library.org/kvh_search/ itemDetail.jsp?id=601 [cit. 2011-10-10]

HAVEL, V. Slovo o slovu. Dostupné z http://vaclavhavel.cz/index.php?sec=2\&id=5 [cit. 2008-10-10]

Obrázky dostupné z: http://eldar.cz/myf/txt/havel_-_antikody.html 